\title{
Mie Kering Berbahan Baku Ubi Jalar (Formulasi, Proses Produksi, Karakteristik Produk)
}

\author{
Dewi Sarastani \\ Program Keahlian Supervisor Jaminan Mutu Pangan - Program Diploma - IPB \\ dewi_astani@yahoo.com
}

\begin{abstract}
The purpose of this research is to study the processing of Ipomoea batatas $L$ based dry noodle. Dry noodle is successfully made from corm of the Ipomoea batatas $L$, without starting from flour. Noodle's production steps are braising of corm, mixing corm with supplement material, braising of noodle dough, making of noodle sheets, steaming and drying the noodle's circuits, dry noodle's packaging. The result shows that mie[noodle] from purple parsnip have organoleptic's score to perceive, color, aroma, and elasticity that equals with mie from wheat, but has ekstensibility's score inferior than mie from wheat. Chemical contents of Purple Parsnip's mie are $11.34 \%$ of moisture content, $6.68 \%$ of protein, $0.94 \%$ of fat, $5.02 \%$ of ash, and $1.1 \%$ of fiber. According to Indonesian National Standart [number 013551 2000], the moisture and protein content of Purple Parsnip's mie meet to instant mie specification.
\end{abstract}

Keyword : corm, Ipomoea batatas L, mie

\section{PENDAHULUAN}

\section{Latar Belakang}

Perkembangan pesat konsumsi mie di Indonesia, memberi pelajaran bahwa mie merupakan jenis makanan yang sesuai dengan kebutuhan atau kesukaan konsumen Indonesia, bahkan dapat dikatakan mie telah menjadi pangan alternatif utama setelah nasi. Di sisi lain konsumsi mie berpeluang menurunkan devisa negara karena mie merupakan produk berbahan baku tepung terigu yang merupakan komoditas impor, sementara Indonesia mampu menghasilkan beragam komoditas sumber karbohidrat yang perlu ditingkatkan pemanfaatannya terutama untuk penyediaan pangan alternatif bagi masyarakat (Munarso dan Haryanto, 2010). Propinsi Jawa Barat merupakan daerah potensial penghasil ubi jalar, bahkan merupakan propinsi urutan pertama penghasil ubi jalar terbesar di Indonesia (Tabel 1). Umbi ubi jalar merupakan bahan pangan sumber karbohidrat, dan teknologi pengolahan mie dapat diterapkan pada bahan pangan non terigu. Keadaan tersebut menggelitik dan membangun impian peneliti, menjadikan ubi jalar diolah menjadi mie kering yang dapat menjadi salah satu alternatif pangan utama selain nasi, bagi masyarakat Indonesia.

Tabel 1. Data statistik lima propinsi terbesar penghasil ubi jalar di Indonesia*

\begin{tabular}{lccccc}
\hline \multicolumn{1}{c}{ Propinsi } & \multicolumn{5}{c}{ Produksi Ubi Jalar (ton/tahun) } \\
& $\mathbf{2 0 0 5}$ & $\mathbf{2 0 0 6}$ & $\mathbf{2 0 0 7}$ & $\mathbf{2 0 0 8}$ & $\mathbf{2 0 0 9}$ \\
\hline Jawa Barat & 390.386 & 389.043 & 375.714 & 376.490 & 389.851 \\
Papua & 273.876 & 290.424 & 306.804 & 337.096 & 334.235 \\
Jawa Timur & 150.564 & 150.540 & 149.811 & 136.556 & 144.659 \\
Jawa Tengah & 144.598 & 123.485 & 143.364 & 117.159 & 119.670 \\
Sumatera Utara & 115.728 & 102.712 & 117.641 & 114.186 & 142.602 \\
\hline
\end{tabular}

*Biro Pusat Statistik [2010] 


\section{Tujuan Penelitian}

Penelitian ini bertujuan mempelajari proses produksi mie kering dari umbi ubi jalar. Proses produksi mie tersebut meliputi : pencarian formulasi, tahap pengolahan dan pengeringan, karakteristik dan kualitas mie ubi jalar.

\section{Bahan}

\section{METODOLOGI}

Bahan yang digunakan dalam penelitian ini meliputi bahan baku mie, bahan tambahan. Mie, bahan analisis kimia mie. Bahan baku mie yang digunakan terdiri dari umbi ubi jalar putih, ubi jalar kuning, ubi jalar orange, dan ubi jalar ungu. Bahan tambahan mie yang digunakan meliputi : tepung tapioka, tepung terigu, tepung sagu, telur, garam, dan minyak goreng. Bahan-bahan tersebut dibeli di pasar lokal yang ada di kota Bogor.

\section{Alat}

Peralatan yang digunakan untuk membuat mie kering terdiri dari : alat pengukus, kompor, baskom, cetakan mie, alat penipis dan pemotong lembaran mie, alat pengering mie molen dryer, oven, penggorengan, kipas angin. Peralatan untuk pengujian organoleptik mie rehidrasi meliputi : kompor, panci, peniris, piring, garpu, gelas. Selain itu diperlukan serangkaian peralatan untuk analisis proksimat mie (kadar air, protein, lemak, abu, dan serat).

\section{Metode}

Formulasi yang digunakan dalam pembuatan adonan mie ubi jalar tersaji pada Tabel 2. Tahap pengolahan dan pengeringan mie ubi tersaji pada Gambar 1.

Mie kering ubi yang memiliki karakterististik terpilih, dilakukan pengujian organoleptik terhadap mie rehidrasinya. Metode uji organoleptik yang digunakan adalah metode uji Kesukaan (uji Hedonik). Panelis yang terlibat dalam pengujian ini berjumlah 34 orang, terdiri dari panelis agak terlatih, 31 orang mahasiswa Program Keahlian Supervisor Jaminan Mutu Pangan Diploma-IPB (7 pria, 24 wanita), dan 3 orang karyawati-Diploma. Parameter mutu organoleptik mie rehidrasi yang diuji adalah rasa, warna, aroma, kekenyalan, dan ekstensibilitas. Mie rehidrasi disiapkan dengan merebus mie kering dengan air mendidih selama kurang lebih 3-5 menit, kemudian disajikan di piring. Setiap panelis menghadapi 7 macam contoh mie, segelas air minum penetral, 1 lembar format uji.

Data pengujian organoleptik yang diperoleh kemudian diolah dengan program SPSS (Statistical Program for Social Science) versi 11 meliputi uji statistik Sidik Ragam dan uji lanjutan Duncan. Mie Ubi yang paling disukai konsumen dari pengujian ini, selanjutnya diuji secara kimiawi mengenai kandungannya (kadar air, protein, lemak, abu, dan serat) dengan metode uji Proksimat.

Tabel 2. Formulasi adonan mie ubi

\begin{tabular}{cl}
\hline Bahan Baku & \multicolumn{1}{c}{ Bahan Tambahan } \\
\hline Ubi jalar putih & Tepung terigu 15\%; Tepung tapioka/tepung sagu 15\% \\
& Telur 5\% / 10\%;Garam 2\% \\
Ubi jalar kuning & Tepung terigu 15\%; Tepung tapioka/tepung sagu 15\% \\
& Telur 5\% / 10\%; Garam 2\% \\
Ubi jalar orange & Tepung terigu 15\%; Tepung tapioka/tepung sagu 15\% \\
& Telur 5\% / 10\%; Garam 2\% \\
Ubi jalar ungu & Tepung terigu 15\%; Tepung tapioka/tepung sagu 15\% \\
& Telur 5\% / 10\%; Garam 2\% \\
\hline
\end{tabular}




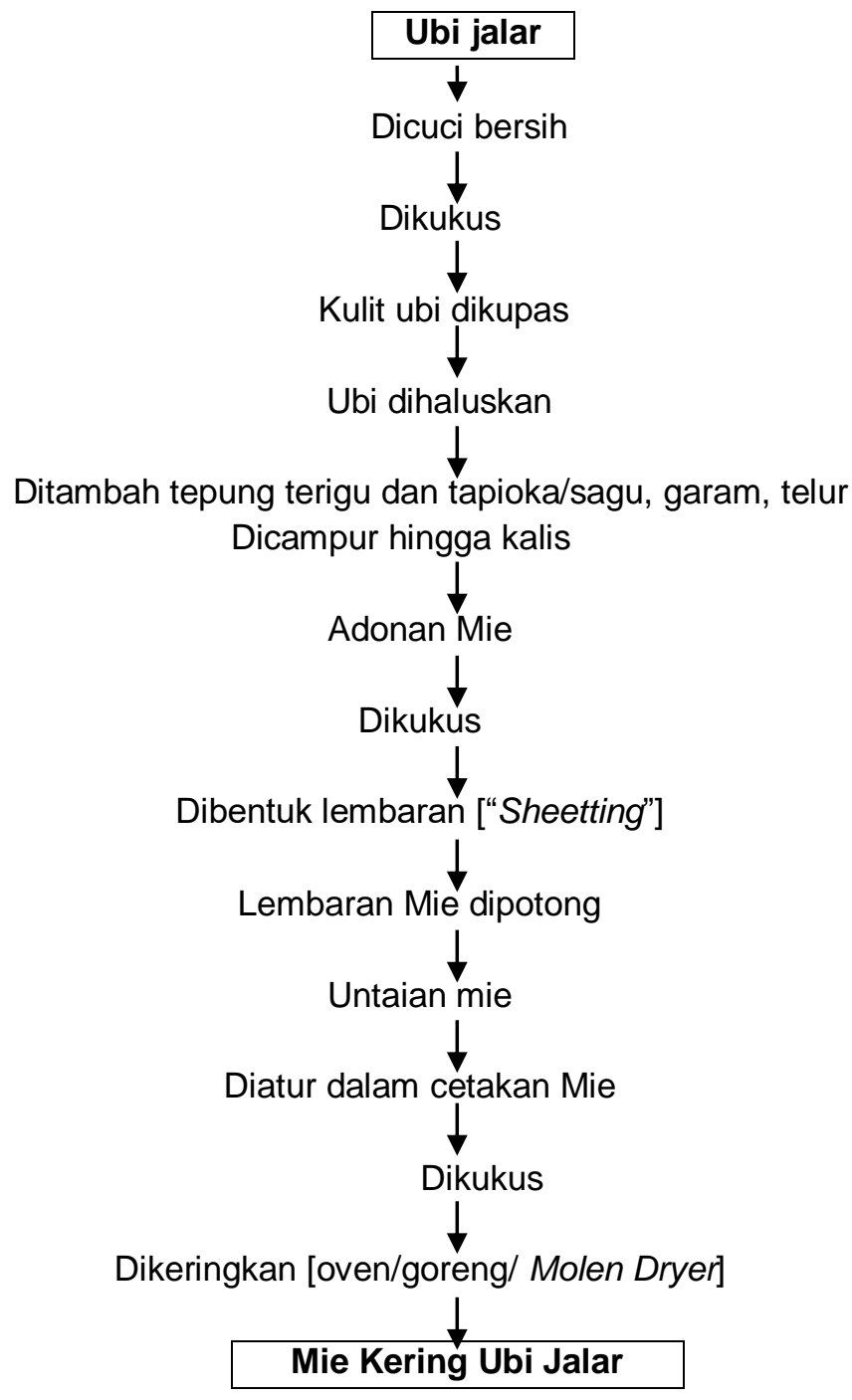

\section{Gambar 1. Tahap Pengolahan Mie Kering Ubi Jalar.}

\section{Formulasi mie ubi}

\section{HASIL DAN PEMBAHASAN}

Bahan baku mie kering ubi jalar dalam penelitian ini adalah umbi ubi jalar dalam keadaan utuh, bukan dalam bentuk tepung ataupun pati. Alasan utama adalah lebih praktis dan murah, karena umbi ubi jalar tanpa perlu proses pengolahan lebih dulu menjadi tepung ataupun pati, sehingga menghemat waktu dan biaya. Kekurangannya, daya simpan umbi lebih pendek daripada tepung atau pati, serta umbi memerlukan sedikit lebih banyak ruang penyimpanan. Bahan tambahan yang digunakan dalam pembuatan mie ubi ini adalah campuran tepung terigu dengan tepung tapioka atau tepung sagu. Tujuan penggunaan tepung terigu adalah pertimbangan kandungan protein terigu [glutenin dan gliadin] yang membentuk gluten dan akan menyumbang karakter elastik-kenyal pada produk mie. Tepung tapioka atau sagu diharapkan kandungan amilopektinnya yang tinggi dapat memberi efek kental dan lengket pada produk mie, sehingga tidak pera atau keras.

Formula campuran dari ketiga bahan : ubi jalar kukus, tepung terigu, tepung tapioka/ tepung sagu, sudah dapat menghasilkan produk mie ubi. Formula tersebut memberikan rasa mie rehidrasi ubi orange paling manis, mie ubi kuning dan ungu 
berasa manis, sementara mie ubi putih tidak berasa manis. Aroma manis ubi juga terdeteksi pada mie ubi orange, kuning, ungu, sementara pada mie ubi putih beraroma agak manis. Tekstur mie ubi kuning diperoleh paling kenyal dan lengket, mie ubi putih kenyal dan agak lengket, mie ubi orange kurang kenyal dan lengket, mie ubi ungu kurang kenyal dan tidak lengket. Warna mie ubi tetap seperti warna daging ubi: putih, kuning, orange, dan ungu.

Formula dasar mie ubi kering tersebut diatas, kemudian diperkaya dengan penambahan telur $5 \%$ atau $10 \%$, dan garam $2 \%$. Telur diharapkan selain meningkatkan nutrisi mie, juga diharapkan dapat memberikan karakter mie lebih kenyal, kompak, dan tidak lengket. Hasil percobaan menunjukkan bahwa mie yang diperkaya dengan telur $10 \%$, memberi tekstur lebih kenyal dan tidak lengket, dibandingkan mie yang diperkaya dengan telur $5 \%$. Penambahan garam pada adonan mie, memberikan karakter mie rehidrasinya berasa gurih, tetapi menghilangkan rasa dan aroma manis ubi. Formulasi akhir yang digunakan dalam penelitian ini yaitu umbi ubi jalar kukus, ditambah $15 \%$ terigu, $15 \%$ tapioka/sagu, $10 \%$ telur, dan $2 \%$ garam.

\section{Pengolahan mie ubi}

Pembuatan mie ubi diawali dengan pencucian ubi dengan air dan penggosokan kulit, kemudian dilakukan pengukusan ubi hingga matang. Pengukusan ini berfungsi untuk mengempukkan daging ubi dengan uap panas, selain itu uap air akan terserap oleh daging ubi. Air ini akan menjadi bahan pelarut dalam pembuatan adonan mie, sehingga tidak perlu penambahan air lagi. Air tersebut akan membasahi campuran tepung terigu dan tepung tapioka/sagu, sehingga terbentuk adonan mie yang kalis. Pengukusan ubi dilakukan dengan alat panci kukus selama kurang lebih 30-40 menit, dilanjutkaan dengan penghalusan ubi kukus, penambahan bahan lain, dan pembentukan adonan mie.

Adonan mie, selanjutnya dibentuk pipih dan dikukus kembali kurang lebih 15 menit. Umumnya pada pembuatan mie dari tepung, setelah terbentuk adonan mie langsung dilakukan penipisan adonan atau pembuatan lembaran mie, tetapi pada pengolahan mie ubi, diperlukan pengukusan adonan terlebih dahulu sebelum dibuat lembaran mie. Hal ini diperlukan agar untaian mie tidak mudah putus. Pengukusan ini memberikan dampak tergelatinisasinya tepung terigu dan tepung tapioka/sagu oleh uap panas, sehingga adonan lebih kuat dan kompak.

Adonan mie setelah dikukus, dibiarkan dingin di suhu ruang, selanjutnya dilakukan penipisan adonan dan pembentukan lembaran mie dengan alat "Noodle Sheeter". Penipisan dilakukan berulang, mulai dengan ketebalan besar sampai ketebalan semakin tipis, yaitu sampai ketebalan yang diinginkan, yaitu antara 1-2 mm. Ukuran ketebalan dapat diatur dengan mengubah rongga/jarak alat penipis lembaran mie. Setelah lembaran tipis terbentuk, dilanjutkan dengan pemotongan lembaran mie membentuk untaian mie. Kekuatan untaian mie secara fisik dipengaruhi oleh kombinasi ketebalan dan lebar lembaran mie, selain itu juga dipengaruhi oleh kandungan bahan adonan mie.

Untaian mie ubi selanjutnya diletakkan pada cetakan mie, kemudian langsung dikukus selama $\pm 5-10$ menit. Cetakan mie berfungsi untuk: memberi bentuk mie kering, mencegah mie basah lengket dengan alat kukus, dan memudahkan pemindahan mie saat pengeringan, sehingga bentuk akhir mie kering seragam. Pengukusan untaian mie ini, juga difungsikan untuk pratanak lebih lanjut dari mie ubi.

Proses pengurangan kadar air mie ubi, dilakukan dengan : mie basah digoreng secara deep frying, dikeringkan dengan oven, atau dikeringkan dengan penghembusan 
udara panas dari alat molen dryer. Pengeringan dengan metode penghembusan udara panas dari alat molen dryer memberi penampakan mie kering yang paling bagus.

Penampakan mie kering terbaik diperoleh dengan pengeringan molen dryer, hal ini disebabkan udara panas yang dihembuskan bersuhu tidak terlalu panas $\left[ \pm 60-70{ }^{\circ} \mathrm{C}\right]$, suhu dapat konstan, tidak fluktuatif. Berbeda dengan alat pengering oven gas, dimana kestabilan suhu tidak terjamin karena keterbatasan kemampuan alat yang mana tidak terdapat alat penstabil suhu. Pada alat oven, meski di awal proses, suhu pemanasan telah diatur sekitar $60-70^{\circ} \mathrm{C}$, tetapi pada perjalanannya suhu oven gas dapat jauh lebih tinggi dari suhu tersebut. Pengendalian suhu oven hanya dapat dilakukan dengan buka/tutup pintu oven. Hal ini berakibat mie ubi yang dihasilkan menjadi kecoklatan dan tidak seragam.

\section{Karakteristik mie ubi}

Dari berbagai jenis mie yang telah dibuat, dipilih beberapa mie untuk dilakukan pengujian organoleptik terhadap mie rehidrasinya. Pemilihan jenis mie didasarkan pada: penampakan organoleptik mie kering dan mutu organoleptik mie rehidrasinya, sehingga terpilih 6 jenis mie ubi kering untuk pengujian organoleptik. Keenam jenis mie kering terpilih adalah : Mie ubi-orange-tapioka-molen, mie ubi-orange-sagu-molen , mie ubi putih-tapioka-molen, mie ubi kuning-tapioka-molen, mie ubi putih-sagu-molen, Mie ubi ungu-sagu- molen [860], dan mie pembanding terigu [870].

Karakteristik dari setiap jenis mie rehidrasi terpilih terangkum di Tabel 3, tersaji dengan nilai rataan dari penilaian organoleptik oleh 34 panelis terhadap parameter rasa, warna, aroma, kekenyalan dan ekstensibilitas. Hasil jajak pendapat dari 34 panelis menunjukkan bahwa atribut pertama yang perlu dilihat dari suatu mie rehidrasi adalah rasa dan warna mie, kemudian aroma, kekenyalan, dan terakhir ekstensibilitas mie.

Tabel 3. Rataan Penilaian Organoleptik dari Uji Kesukaan terhadap Mie Ubi

\begin{tabular}{|l|l|l|l|l|l|}
\hline \multicolumn{1}{|c|}{ Jenis Mie } & Rasa & Warna & Aroma & Kekenyalan & Ekstensibilitas \\
\hline Mie Ubi Orange-Tapioka & $4,32^{\mathrm{b}}$ & $4,65^{\mathrm{a}}$ & $3,38^{\mathrm{c}}$ & $3,74^{\mathrm{c}}$ & $3,44^{\mathrm{b}}$ \\
\hline Mie Ubi Orange-Sagu & $4,21^{\mathrm{b}}$ & $4,06^{\mathrm{b}}$ & $3,38^{\mathrm{c}}$ & $3,56^{\mathrm{c}}$ & $3,26^{\mathrm{b}}$ \\
\hline Mie Ubi Putih -Tapioka & $3,7^{\mathrm{c}}$ & $3,85^{\mathrm{b}}$ & $3,85^{\mathrm{b}}$ & $3,85^{\mathrm{c}}$ & $3,38^{\mathrm{b}}$ \\
\hline Mie UbiKuning-Tapioka & $3,2^{\mathrm{c}}$ & $2^{\mathrm{c}}$ & $3,47^{\mathrm{c}}$ & $2,65^{\mathrm{d}}$ & $2,56^{\mathrm{c}}$ \\
\hline Mie Ubi Putih-Sagu & $4,21^{\mathrm{b}}$ & $3,91^{\mathrm{b}}$ & $4,21^{\mathrm{a}}$ & $4,15^{\mathrm{b}}$ & $3,88^{\mathrm{b}}$ \\
\hline Mie Ubi Ungu-Sagu & $4,38^{\mathrm{a}}$ & $\mathbf{4 , 7 4 ^ { \mathrm { a } }}$ & $4,35^{\mathrm{a}}$ & $4,56^{\mathrm{a}}$ & $3,91^{\mathrm{b}}$ \\
\hline Mie Terigu & $\mathbf{4 , 4 1 ^ { \mathrm { a } }}$ & $\mathbf{4 , 6 2 ^ { \mathrm { a } }}$ & $\mathbf{4 , 5 6 ^ { \mathrm { a } }}$ & $\mathbf{4 , 8 5 ^ { \mathrm { a } }}$ & $\mathbf{5 , 2 1 ^ { \mathrm { a } }}$ \\
\hline a,b,c hasil uji Duncan & & & & & \\
\hline
\end{tabular}

Tabel 3 menunjukkan rataan penilaian panelis terhadap rasa, warna, aroma, kekenyalan, ekstensibilitas mie rehidrasi, berkisar dari skala tidak suka [2] kearah suka [6]. Data hasil pengujian organoleptik ini kemudian diolah statistik dengan Uji Sidik Ragam Anova dan uji Duncan menggunakan program komputer SPSS versi 11. Pengolahan statistik Anova memberikan hasil bahwa perlakuan jenis mie memang sangat nyata mempengaruhi penilaian organoleptik terhadap rasa, warna, aroma, kekenyalan, dan ekstensibilitas mie rehidrasi. Oleh karena itu perlu uji statistik lanjutan, berupa uji Duncan. 
Hasil uji Duncan terhadap rasa, warna, aroma, kekenyalan, dan ekstensibilitas mie rehidrasi tersaji di Tabel 3 . Keenam jenis mie ubi terpilih diuji dan dibandingkan secara organoleptik dengan mie terigu sebagai pembanding, diperoleh hasil analisis Duncan bahwa mie ubi ungu-sagu memiliki penilaian rasa, warna, aroma, dan kekenyalan yang sama dengan mie terigu, tetapi memiliki ekstensibilitas lebih rendah dibanding mie terigu, yaitu dari skala hedonik biasa [3] ke suka[6]. Penilaian kedua produk mie terhadap kelima parameter mutu organoleptik diwujudkan dengan diagram jaring laba-laba pada gambar 2. Kandungan kimiawi mie ubi ungu-sagu diuji dengan analisis proksimat, meliputi kadar air, protein, lemak, abu, dan serat. Hasil analisis ini tersaji di Tabel 4.

Tabel 4. Kandungan kimiawi mie kering berbahan baku ubi jalar ungu

\begin{tabular}{lc}
\hline \multicolumn{1}{c}{ Jenis kandungan } & Persentase \\
\hline Kadar air $(\%)$ & 11,34 \\
Protein $(\% \mathrm{~b} / \mathrm{b})$ & 6,68 \\
Lemak $(\%)$ & 0,94 \\
Serat $(\%)$ & 1,10 \\
Abu $(\%)$ & 5,02 \\
\hline
\end{tabular}

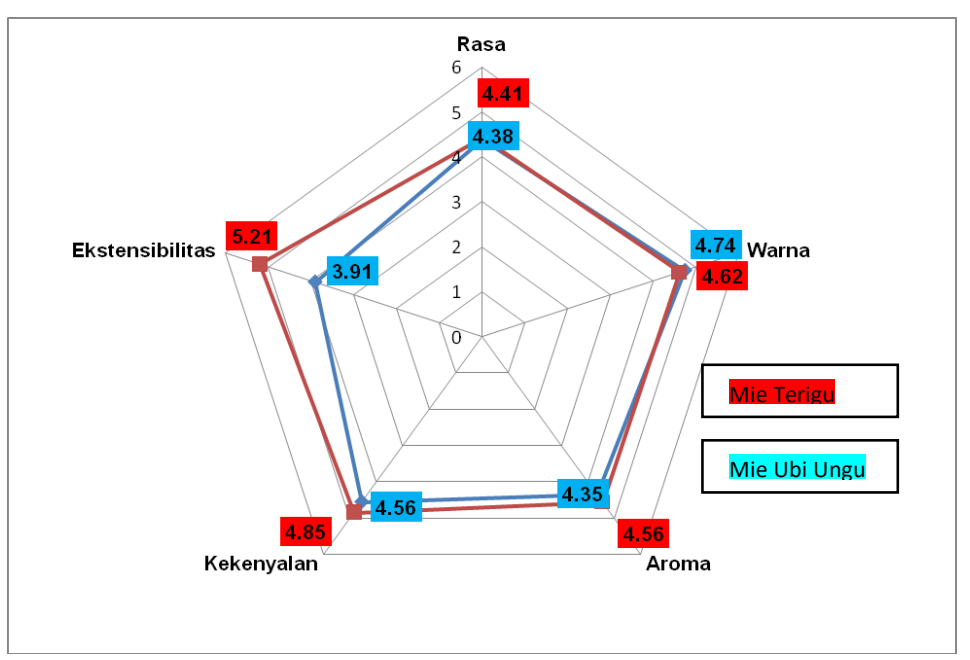

\section{Gambar 2. Rataan Penilaian Organoleptik Mie Ubi Ungu dibandingkan Mie Terigu}

Mie ubi ungu-sagu memiliki kandungan kimiawi sebagai berikut : kadar air sebesar $11,34 \%$ bobot basah, protein 6,68\%, lemak 0,94\%, abu 5,02\%, dan kadar serat $1,1 \%$. Bila dibandingkan dengan Standar Nasional Indonesia [SNI] nomor 01-3551-2000 untuk mie Instan (kadar air mie instan maksimum 14,5\% bobot basah, kadar protein mie non terigu minimal 4\%), maka persyaratan kadar air dan kadar protein mie kering ubi ungu memenuhi standar SNI.

\section{SIMPULAN}

Dari penelitian ini diperoleh hasil bahwa mie kering dapat dibuat langsung dari umbi ubi jalar, baik dari ubi jalar warna putih, kuning, orange, maupun ungu. Tidak diperlukan pengolahan ubi menjadi tepung atau pati terlebih dahulu dalam pembentukan adonan mie ubi. Secara keseluruhan dapat disimpulkan proses pembuatan mie kering ubi relatif mudah. Dari segi formulasi, mie kering ubi ini memerlukan bahan pengisi dan pengikat berupa campuran terigu dan tapioka/sagu 
sebesar $30 \%$. Kandungan kimia mie ubi ungu [ kadar air dan protein] telah memenuhi standar SNI nomor 01-3551-2000 untuk mie Instan.

Mie kering ubi potensial dikembangkan menjadi makanan alternatif masyarakat Indonesia. Mengingat kandungan $\beta$-karoten pada ubi kuning dan orange serta kandungan antocyanin pada ubi ungu, mie kering ubi juga potensial dikembangkan menjadi makanan funsional. Komponen $\beta$-karoten merupakan provitamin- $A$, dan antocyanin dapat berfungsi sebagai antioksidan.

\section{SARAN}

Perlu dilakukan lebih lanjut penelitian ini untuk mendapatkan formulasi optimum mie ubi, termasuk untuk mendapatkan karakteristik mie rehidrasi yang lebih baik. Perlu penelitian lanjutan untuk proses produksi mie ubi dalam skala besar.

\section{DAFTAR PUSTAKA}

Badan Standardisasi Nasional. 2000. Standar Nasional Indonesia Mie Instan No. 013551-2000. BSN, Jakarta.

Biro Pusat Statistik. 2010. Luas panen, Produksi dan Produktivitas Ubi Jalar. http://www.bps.go.id/aboutus.php?tabel=1\&id subyek=55 [Diunduh April 2010].

Munarso, S.J. dan B. Haryanto. 2010. Perkembangan Teknologi Pengolahan Mie. http://www.iptek.net.id/ind/pdf/prosiding/poster/PTP18 BambangHar Pengolahan mie patpi.pdf. [Diunduh April 2010]. 